\title{
Influence of sugar mill effluent on physico-chemical characteristics of soil at Haridwar (Uttarakhand), India
}

\author{
Vinod K umar* and A. K. Chopra \\ Department of Zoology and Environmental Science, Gurukula Kangri University, Haridwar-249404 (Uttarakhand), \\ INDIA \\ *Corresponding author. E-mail: drvksorwal@gmail.com
}

Abstract: The influence of seven rates of Sugar mill effluent (viz. 0, 5, $1025,50,75$ and $100 \mathrm{ml} / \mathrm{kg}$ soil) along with control (Bore-well water, BWW) on the physical and chemical properties of soils revealed that among various concentrations of the effluents, the irrigation with $100 \%$ effluent concentration decreased moisture content $(20.44 \%)$, WHC (13.80\%), BD (4.14\%) and increased pH (9.56\%), EC (64.28\%), ECEC $(149.25 \%)$, Cl (194.71\%), $\mathrm{OC}(3228.89 \%), \mathrm{HCO}_{3}^{-}(22.34 \%), \mathrm{CO}_{3}^{-2}(29.38 \%), \mathrm{Na}^{+}(185.48 \%), \mathrm{K}^{+}(53.40 \%), \mathrm{Ca}^{2+}(1262.24 \%), \mathrm{Mg}^{2+}(1818.24 \%)$, TKN (1206.36\%), $\mathrm{NO}_{3}^{2-}(80.87 \%), \mathrm{PO}_{4}^{3-}(236.04 \%), \mathrm{SO}_{4}^{2-}(72.08 \%), \mathrm{Fe}^{2+}(234.34 \%), \mathrm{Zn}(317.72 \%), \mathrm{Cd}(404.35 \%), \mathrm{Cu}$ (374.90\%), $\mathrm{Pb}(645.71 \%)$ and $\mathrm{Cr}(1024.80 \%)$ in the soil when compared to control. There was a significant $(\mathrm{P}<0.001)$ effect on $\mathrm{EC}, \mathrm{pH}, \mathrm{Cl}, \mathrm{OC}, \mathrm{HCO}_{3}^{-}, \mathrm{CO}_{3}{ }^{-2}, \mathrm{Na}^{+}, \mathrm{K}^{+}, \mathrm{Ca}^{2+}, \mathrm{Mg}^{2+}, \mathrm{Fe}^{2+}, \mathrm{TKN}, \mathrm{NO}_{3}{ }^{2-}, \mathrm{PO}_{4}{ }^{3-}$ and $\mathrm{SO}_{4}{ }^{2-}, \mathrm{Zn}, \mathrm{Cu}, \mathrm{Cd}, \mathrm{Cr}$ and $\mathrm{Pb}$ and insignificant $(\mathrm{P}>0.05)$ effect on moisture content, $\mathrm{WHC}$ and bulk density after sugar mill effluent irrigation when compared to control. There was no momentous change in the soil texture of the soil. The enrichment factor (Ef) of various micronutrients in the soil was recorded in order of $\mathrm{Cr}>\mathrm{Pb}>\mathrm{Cd}>\mathrm{Cu}>\mathrm{Zn}$ after irrigation with sugar mill effluent.

Keywords: Sugar mill effluent, Irrigation, Soil characteristics, Micronutrients, Enrichment factor (Ef)

\section{INTRODUCTION}

The disposal of wastewater is a major problem faced by industries, due to generation of high volume of effluent and with limited space for land based treatment and disposal. On the other hand, wastewater is also a resource that can be applied for productive uses since wastewater contains nutrients that have the potential for use in agriculture, aquaculture, and other activities (Hussain et al., 2001). The wastewater effects on soils and crops are of more concern to people when the irrigant is wastewater which may contain agents capable of inducing adverse effects on the soil media and the agricultural products. The sugar industry is playing an important role in the economic development of the Indian sub continent, but the effluents released produce a high degree of organic pollution in both aquatic and terrestrial ecosystems. They also alter the physico-chemical characteristics of the receiving aquatic bodies and affect aquatic flora and fauna. Sugar mill effluent, when discharged into the environment, poses a serious health hazard to the rural and semi-urban populations that uses stream and river water for agriculture and domestic purposes, with reports of fish mortality and damage to the paddy crops. Farmers have been using these effluents unscientifically for irrigation, and found that the growth, yield and soil health were reduced. Contaminants, such as chloride, sulphate, phosphate, magnesium and nitrate, are discharged with the effluent of various industries, which create a nuisance due to physical appearance, odour and taste (Baruah et al., 1993). Presently India has nearly 650 sugar mill that produce about 15 million tons of sugar and 13 million tons of molasses. Sugar mills account in the industries which discharge huge amount of effluent per day without any or partially treatment during the crushing season. It has also been reported that sugar mill effluent contains high magnitude of pollution load and caused adverse effect on soil and biological system (Arindam and Prasad, 1999; Sanjay, 2005 and Ayyasamy et al., 2008). Most crops give higher potential yields with wastewater irrigation; reduce the need for chemical fertilizers, resulting in net cost savings to farmers. Thus it is an important to understand the specificity of crop-effluent liaison for their appropriate application in irrigation practices (Vinod et al., 2010). In recent past various studies have been made on the characteristics of effluent of industries, agronomical properties of various crop plants (Osemwota et al., 2000; Gomez et al., 2001; Ramana et al., 2002; TseMing et al., 2004; García-Orenes et al., 2005; Kaushik et al., 2005; Osemwota et al., 2005; Nastri et al., 2006; Sharif et al., 2006; Hati et al., 2007; Roy et al., 2007; Afshin et al., 2008; Beligh et al., 2007; Bharagava et al., 2008; ChinChing et al., 2008; Kannan and Upreti, 2008; Patterson et al., 2008; Biswas et al., 2009; Chandra et al., 2009; Chopra et al., 2009; Hassanli et al., 2009; Jeremy et al., 2009; 
Mohammadi et al., 2010; Osadebamwen, 2010; Stoecio et al., 2010; and Vinod et al., 2010). Keeping in view the above facts, a field experiment was conducted to study the effect of graded doses of Sugar mill effluent application on the physical and physico-chemical properties of a loamy sand soil at Haridwar (Uttarakhand).

\section{MATERIALS AND METHODS}

Experimental design: A field study was conducted in the Experimental Garden of the Department of Zoology and Environmental Sciences, Faculty of Life Sciences, Gurukula Kangri University Haridwar, for studying the irrigation effect of sugar mill effluent on soil characteristics. Pots used for the experiment was laid under completely randomized design, replicated by six times and was labeled for the various treatments viz. 0,5, $10,25,50,75$ and $100 \%$.

Effluent collection and analysis: R.B.N.S. sugar mill, Laksar, Haridwar (Uttarakhand) which produces sugar as its main product from sugarcane was selected for the collection of effluent samples. The effluents (SME) were collected from outlet of the secondary settling tank installed in the campus of Sugar mill to reduce the BOD and solids using plastic container. The sugar mill effluent was brought to the laboratory and was analyzed for various physico-chemical and microbiological parameters viz. TS, TDS, TSS, EC, turbidity and $\mathrm{pH}, \mathrm{DO}, \mathrm{BOD}, \mathrm{COD}$, TKN, $\mathrm{P}, \mathrm{K}^{+}, \mathrm{Ca}^{2+}, \mathrm{Mg}^{2+}, \mathrm{Cl}^{-}$, and $\mathrm{HCO}_{3}{ }^{-} \mathrm{CO}_{3}{ }^{2-}, \mathrm{Fe}, \mathrm{Zn}, \mathrm{Cd}$, $\mathrm{Cu}, \mathrm{Cr}$ and $\mathrm{Pb}$ content following standard methods (APHA, 2005).

Soil preparation, filling of pots, sampling and analysis: The soil used was collected at a depth of $0-15 \mathrm{~cm}$. Each pot $(30 \times 30 \mathrm{~cm}$.) was filled with $5 \mathrm{Kg}$ well prepared soil, earlier air-dried and sieved to remove debris and mixed with equal quantity of farmyard manure. Five $\mathrm{Kg}$ of soil in each of the forty two of the pots were irrigated weekly with $500 \mathrm{~mL}$ of sugar mill effluent in six concentrations $5 \%, 10 \%, 25 \%, 50 \%, 75 \%$ and $100 \%$ along with bore well water (control). The soil was analyzed before after effluent irrigation as per effluent concentration for various physico-chemical following standard methods (Buurman et al., 1996 for moisture content and EC), (Bouyoucos, 1962 for soil texture), (Carter, 1993 for bulk density, and WHC). The soil $\mathrm{pH}$ was determined using glass electrode pH meter and $\mathrm{Cl}^{-}, \mathrm{OC}, \mathrm{HCO}_{3}^{-}, \mathrm{CO}_{3}^{-2}, \mathrm{Na}^{+}, \mathrm{K}^{+}, \mathrm{Ca}^{2+}, \mathrm{Mg}^{2+}$, $\mathrm{Fe}^{2+}, \mathrm{TKN}, \mathrm{NO}_{3}^{2-}, \mathrm{PO}_{4}^{3-}$ and $\mathrm{SO}_{4}^{2--}$ and heavy metals $\mathrm{Zn}$, $\mathrm{Cd}, \mathrm{Cu}, \mathrm{Cr}$ and $\mathrm{Pb}$ were determined by using standard methods (APHA, 2005).

$\mathrm{H}$ eavy metals analysis: For heavy metal analysis, $5-10 \mathrm{ml}$ sample of effluent, $0.5-1.0 \mathrm{~g}$. sample of air dried soil was taken in digestion tube and add $3 \mathrm{~mL}$ conc. $\mathrm{HNO}_{3}$ digest on electrically heated block for 1 hour at $145^{\circ} \mathrm{C}$. Then add $4 \mathrm{~mL}$ of $\mathrm{HClO}_{4}$ and heated to $240^{\circ} \mathrm{C}$ for an additional hour. Cool and filter through Whatman \# 42 filter paper and makeup volume $50 \mathrm{~mL}$ and used for analysis following standard methods (Tan, 1996; APHA, 2005). The enrichment factor (Ef) for heavy metals accumulated in sugar mill effluent irrigated soil was calculated by following (Kim and Kim, 1999).

Enrichment factor $(\mathrm{Ef})=\frac{\text { Mean metal concentration of sample }}{\text { Metal concentration of reference }}$

Statistical analysis: Data were analyzed for one way analysis of variance (ANOVA) for determining the difference between soil parameters before and after irrigation with different effluent concentration, standard deviation, linear regression for soil parameters with effluent concentration were also calculated with the help of MS Excel, SPSS12.0 and Sigma plot, 2000.

\section{RESULTS AND DISCUSSION}

Characteristics of effluent: The mean \pm SD values of physico-chemical and microbiological parameters TS,

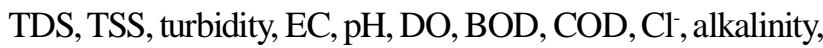
hardness, $\mathrm{HCO}_{3}^{-}, \mathrm{CO}_{3}^{-2}, \mathrm{Na}^{+}, \mathrm{K}^{+}, \mathrm{Ca}^{2+}, \mathrm{Mg}^{2+}, \mathrm{TKN}, \mathrm{NO}_{3}{ }^{2-}$ $, \mathrm{PO}_{4}^{3-}, \mathrm{SO}_{4}^{2-}, \mathrm{Fe}^{2+}, \mathrm{Zn}, \mathrm{Cd}, \mathrm{Cu}, \mathrm{Pb}, \mathrm{Cr}, \mathrm{SPC}$ and MPN of sugar mill effluent are given in Table 1.

The results revealed that it was yellowish in color with odor of sugar, alkaline in nature having $\mathrm{pH}$ (8.23). Among various parameters of effluent (100\%), TSS (220.00 mg L $\left.{ }^{1}\right)$, turbidity (32.56 NTU), BOD (1635.50 $\left.\mathrm{mg} \mathrm{L}^{-1}\right)$, COD (2265.00 $\left.\mathrm{mg} \mathrm{L}^{-1}\right), \mathrm{Cl}^{-}\left(1245.75 \mathrm{mg} \mathrm{L}^{-1}\right)$, alkalinity (684.50 mg L-1), hardness (998.50 $\left.\mathrm{mg} \mathrm{L}^{-1}\right), \mathrm{Ca}^{2+}\left(835.00 \mathrm{mg} \mathrm{L}^{-1}\right)$, $\mathrm{Fe}^{2+}\left(22.750 \mathrm{mg} \mathrm{L}^{-1}\right), \mathrm{TKN}\left(136.00 \mathrm{mg} \mathrm{L}^{-1}\right), \mathrm{NO}_{3}^{2-}(782.25$ $\left.\mathrm{mg} \mathrm{L}^{-1}\right), \mathrm{MPN}\left(6.35 \times 10^{6} \mathrm{MPN} 100 \mathrm{ml}^{-1}\right), \mathrm{SPC}\left(7.89 \times 10^{8} \mathrm{SPC}\right.$ $\mathrm{ml}^{-1}$ ) were found beyond the prescribed limit of Indian irrigation standards (BIS, 1991). The alkaline $\mathrm{pH}$ (8.05) and higher total solids (2395.00 $\left.\mathrm{mg} \mathrm{L}^{-1}\right)$, EC (12.8 dS m $\mathrm{m}^{-1}$ ), $\mathrm{Na}\left(3200.00 \mathrm{mg} \mathrm{L}^{-1}\right)$ and COD (142.00 $\left.\mathrm{mgL}^{-1}\right)$ indicated the higher inorganic and organic load in sugar mill effluent of Co-operative Sugar Mill, Rohtak, Haryana, India as also indicated by Kaushik et al. (1996). Ayyasamy et al. (2008) also reported the higher content of solids (1224.00 $\mathrm{mg} \mathrm{L}^{-1}$ ), BOD (1010.00 $\mathrm{mg} \mathrm{L}^{-1}$ ), hardness (1100.00 $\left.\mathrm{mg} \mathrm{L}^{-1}\right)$, $\mathrm{Ca}\left(480.00 \mathrm{mg} \mathrm{L}^{-1}\right), \mathrm{Mg}\left(620.00 \mathrm{mg} \mathrm{L}^{-1}\right)$ and $\mathrm{SO}_{4}^{2-}(400.00$ $\left.\mathrm{mg} \mathrm{L}^{-1}\right)$ in the effluent of a Sugar industry located in Erode district, Tamil Nadu, India.

Characteristics of soil: The mean \pm SD values of various physico-chemical characteristics and heavy metals moisture content; $\mathrm{WHC}, \mathrm{BD}$ and $\mathrm{pH}, \mathrm{EC}, \mathrm{Cl}^{-}, \mathrm{OC}, \mathrm{HCO}_{3}$ $, \mathrm{CO}_{3}^{-2}, \mathrm{Na}^{+}, \mathrm{K}^{+}, \mathrm{Ca}^{2+}, \mathrm{Mg}^{2+}, \mathrm{Fe}^{2+}, \mathrm{TKN}, \mathrm{NO}_{3}^{2-}, \mathrm{PO}_{4}^{3-}, \mathrm{SO}_{4}^{2-}$ and $\mathrm{Zn}, \mathrm{Cd}, \mathrm{Cu}, \mathrm{Pb}$ and $\mathrm{Cr}$ of the soil before and after irrigation with different concentrations of sugar mill effluent viz. $0 \%$ (BWW), 5\%, 10\%, 25\%, 50\%, 75\% and $100 \%$ are given in the Table 2.

The recent studies by Miller and Turk (2002) have indicated that the moisture content of soil is useful and is an important factor which affects the $\mathrm{pH}$, availability of nutrient to plant and aeration. The moisture content 


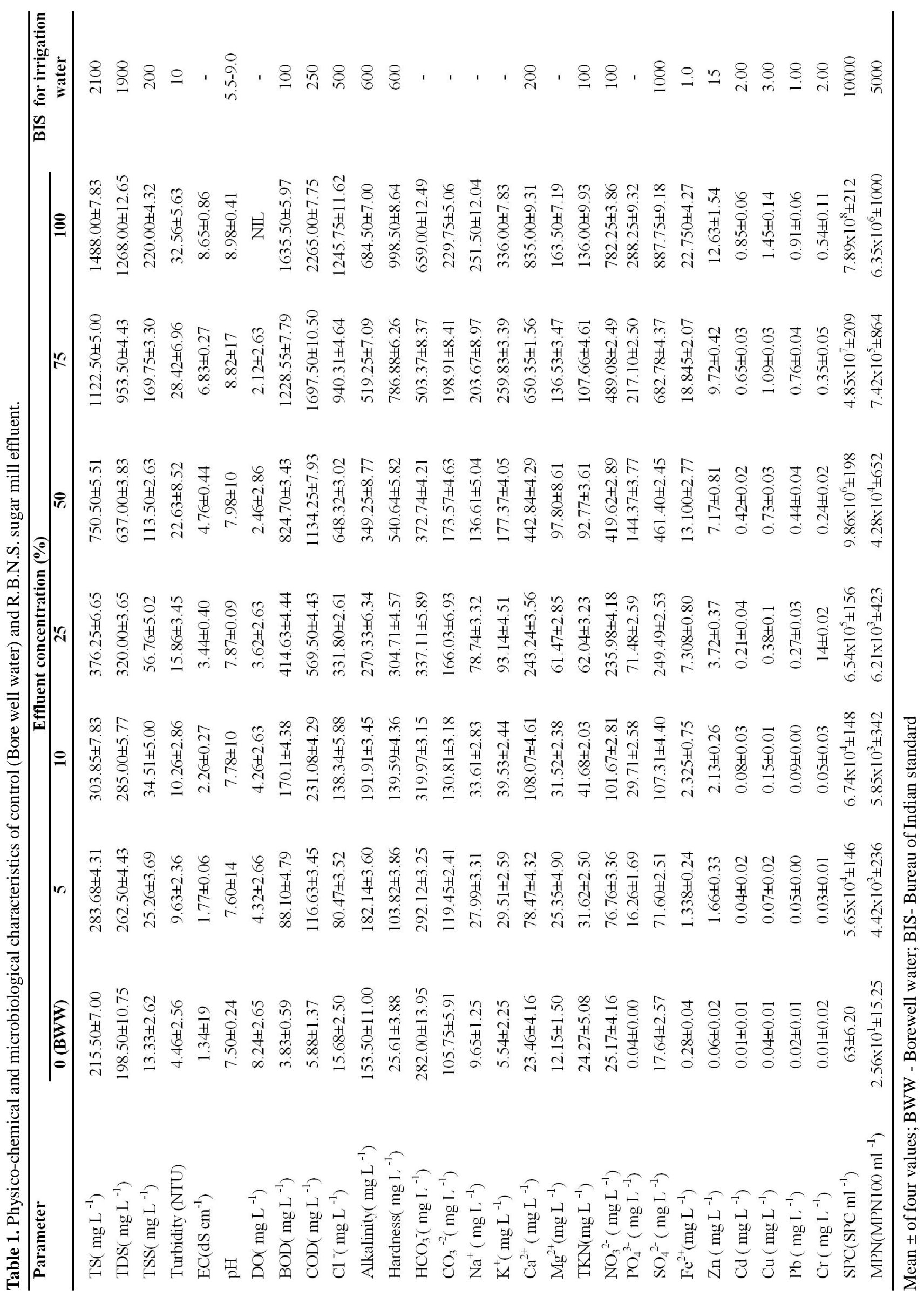


and overall water content in soil at any moment are governed by the amount of water coming and going out from soil. Presence of large soil particles reduces the soil moisture content. The water holding capacity is the amount of water, which is absorbed and retained by the given amount of soil. Water holding capacity is related to the number and size distribution of soil pores and consequently increases with soil organic matter level. It is related to soil moisture content, textural class, structure, salt content and organic matter. Bulk density of soil changes with land use and management practices Fertilizer use and application of organic manure to soil can substantially modify and lower the bulk density of soil, which is useful for root development. Organic matter supplied through the sludge and other kind of wastes also lower the bulk density as stated by (Ramulu, 2001) Charman and Murphy (1991) reported that the basic $\mathrm{pH}$ of the soil is to reduce the solubility of all micronutrients (except chlorine, boron and molybdenum), especially those of iron, zinc, copper and manganese. The soil $\mathrm{pH}$ can also influence plant growth by the $\mathrm{pH}$ effect on activity of beneficial microorganisms. The acidification results in a gradual leaching of basic cations, e.g. $\left(\mathrm{Ca}^{2+}\right.$, $\mathrm{Mg}^{2+}, \mathrm{K}^{+}, \mathrm{Na}^{+}$) from the uppermost horizons, leaving $\mathrm{Al}^{3+}$ as the dominant exchangeable cation. Mohan et al. (2007) found that soil having $\mathrm{pH}$ value 8.5 and above is expected to have more $\mathrm{Na}$ in the exchange complex and when unaccompanied by the presence of soluble salts, is classified as an alkaline soil.

Charman and Murphy (1991) concluded that the EC of water and waste water is due to the presence of total dissolved solids. It is an important criterion to determine the suitability of water and waste water for irrigation. Soils have alkaline $\mathrm{pH}$ levels that are greater than 7 . If these soils have excessive amount of salts (i.e. EC > $4 \mathrm{dS}$ $\mathrm{m}^{-1}$ ) they are classified as saline soils. However if they also contain appreciable exchangeable sodium (sodium absorption ratio SAR >13) or exchangeable sodium percentage $(\mathrm{ESP})>15$ they are classified as saline-sodic. Finally if salt concentration are low $\left(\mathrm{EC}<4 \mathrm{dS} \mathrm{m}^{-1}\right.$ and SAR $>13$ or ESP $>15$ ) high enough to control a soil's chemical attributes, they are known as sodic soils. Carter (1993) reported that ion exchange is one of the most significant functions that occur in soils. Ion exchange is a consequence of mineral charge that is derived from isomorphic substitution, broken edges, and $\mathrm{pH}$ dependent charge sites. These charged sites are the result of ionization $\left(\mathrm{H}^{+}\right.$dissociation) or protonation of uncharged sites; ionization results in a negative charged site and protonation a positive charged site. Both of these reactions are dependent on $\mathrm{pH}$ and are called $\mathrm{pH}$ dependent charge. As the $\mathrm{pH}$ increases, the cation exchange capacity of the soil is generally greater due to an increase in the number of $\mathrm{pH}$ dependent charged sites.
Thompson et al. (2001) concluded that higher concentration of bicarbonates and carbonates increases the sodicity while their lower concentration increases the salinity of the soil. Alkaline soil tends to have high $\mathrm{pH}$ levels and significant amount of $\mathrm{K}, \mathrm{Ca}, \mathrm{Na}$ and $\mathrm{Mg}$ in the soil. Patterson (2008) concluded that higher concentration of $\mathrm{Na}$ causes the decrease the bulk density as well as water holding capacity by reducing the porosity in clay soil due to deflocculating of clay particles in presence of higher $\mathrm{Na}$ content as it affects the cation exchange capacity in the soil and it adversely affects the seed germination and plant growth. Effluent irrigation generally adds significant quantities of salts to the soil environment, such as sulfates, phosphates, bicarbonates, chlorides of the cations sodium, calcium, potassium and magnesium.

Miller and Turk (2002) reported that potassium, $\mathrm{K}^{+}$is a very soluble cation in soil solution, yet it moves only slowly in soils. The $\mathrm{K}$ ions, on being adsorbed by the colloids, displace some other ions such as $\mathrm{Ca}, \mathrm{Mg}$ or $\mathrm{Na}$. The soil cation exchange sites attract potassium ions from water, reducing the potassium mobility through soil. Nitrate is the most essential and available form of nitrogen to plants because plant roots take up nitrogen in the form of $\mathrm{NO}_{3}^{2-}$ and $\mathrm{NH}_{4}^{+}$. The overall increase in nitrogen is due to the use of wastewater, which contains higher amount of nitrogen. When nitrate input exceeds the soil nitrate immobilization potential, a state of $\mathrm{N}$-saturation is said to exist (Aber et al., 1998; Ågren et al., 1998 and AlHarbi, 2008).

Mohammad and Khan (1985) reported that various concentration $(25 \%, 50 \%, 75 \%$ and $100 \%)$ effluent of the Mohan Meak \& Breweries Ltd., Ghaziabad, UP, India (MMBL) rich in ammonia nitrogen, nitrate-nitrogen, phosphorus and potassium, so that its application to the soil increased the available nutrients in the soil. The upper soil had high values of $\mathrm{N}, \mathrm{P}, \mathrm{K}$ and organic matter compared with the lower soil in the pots used. The $\mathrm{pH}$ of the soil decreased gradually with increasing concentration of the effluent. Depletion was noted in the $\mathrm{CaCO}_{3}$ content of the soil irrigated with $100 \%$ and $75 \%$ effluent, while it increased with $25 \%$ and $50 \%$ effluent. The highest perturbance was observed in the available potassium of the soil, when $100 \%$ effluent was used for irrigation followed by $75 \%, 50 \%$ and $25 \%$, and the values of organic matter, ammonia-nitrogen and phosphorus also increased significantly. Mohammad and Khan (1985) reported that the various concentration $(25 \%, 50 \%, 75 \%$ and $100 \%$ ) effluent of the Modi Textile Factory Ltd. Modinagar, UP (MTF) increased the electrical conductivity, cation-exchange capacity, $\mathrm{pH}, \mathrm{NH}_{3}-\mathrm{N}$, phosphorus, organic matter extractable $\mathrm{Na}^{+}, \mathrm{K}^{+}, \mathrm{Ca}^{2+}$ and $\mathrm{Mg}^{2+}$ of the soil. The greatest changes were recorded with $100 \%$ effluent, the most marked increase being in 


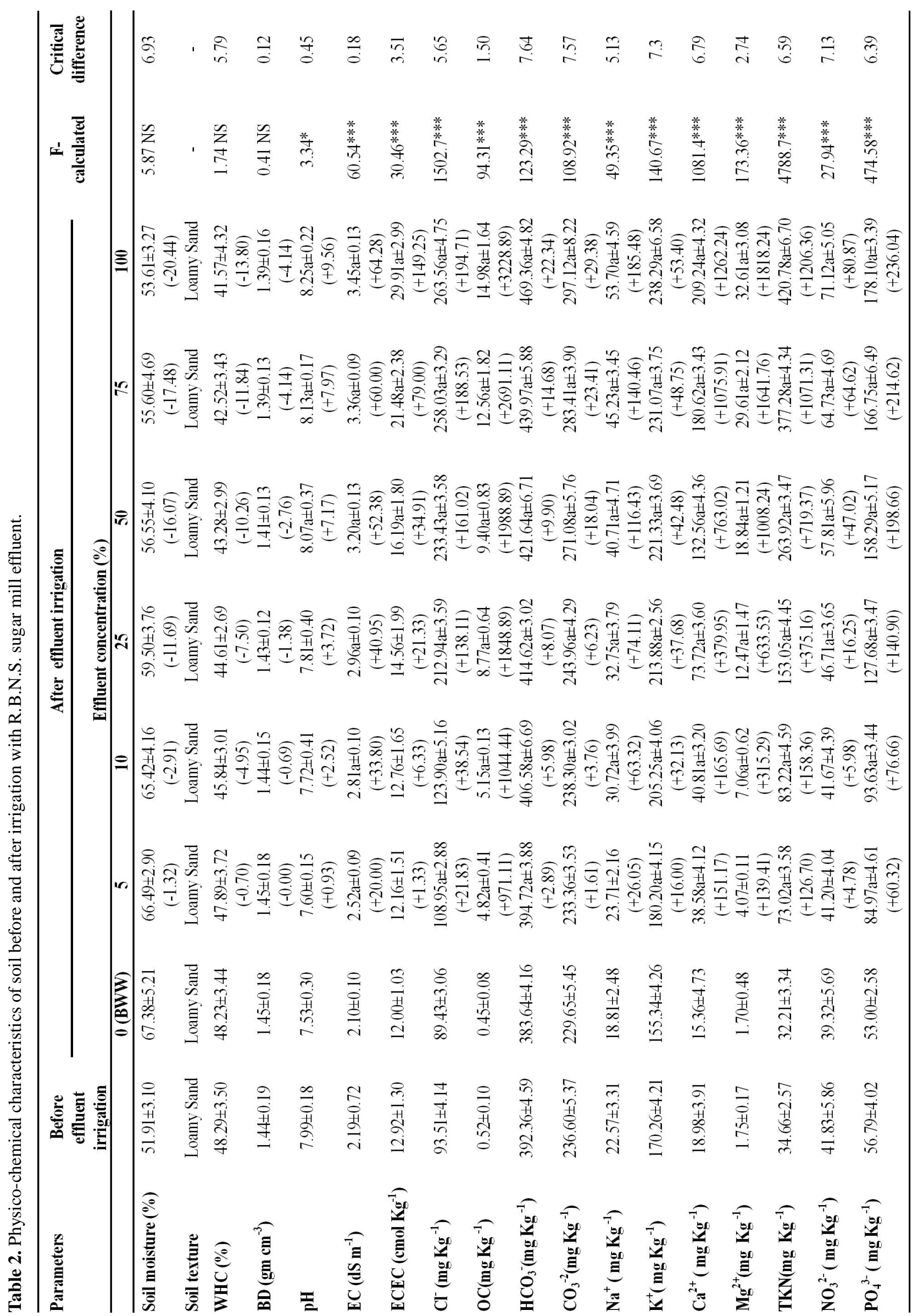




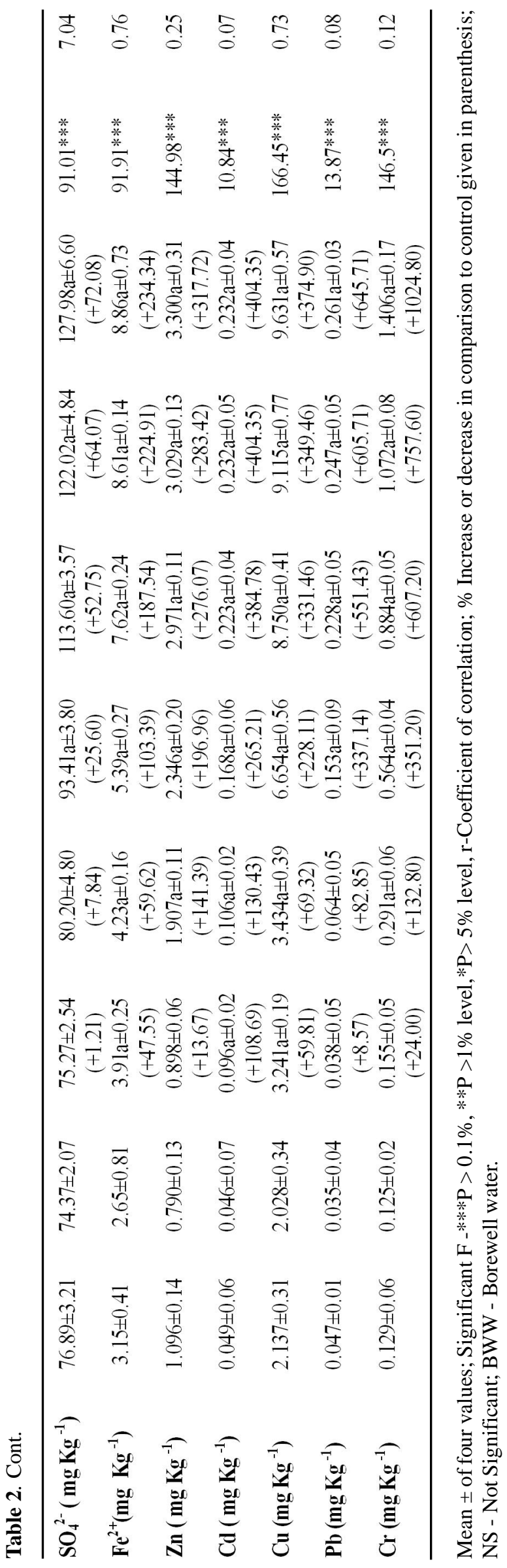

the organic matter of soil, followed by $\mathrm{NH}_{3}-\mathrm{N}, \mathrm{Na}^{+}, \mathrm{K}^{+}$, $\mathrm{Ca}^{2+}$ and $\mathrm{Mg}^{2+}$ of the soil.

Kaushik et al. (2005) reported that long term application of PME proved useful in significantly increasing TOC, TKN, K, P and soil enzymatic activities in the soil but tended to build up harmful concentration of $\mathrm{Na}$, that could be chelated by bioamendments. In short terms studies, application of 50\% PME along with bioamendments proved to be the most useful in improving the properties of sodic soil.

Beligh Mechri (2008) reported that olive mill wastewater irrigation in agriculture, provided that its impact on soil and plant in Mediterranean countries. The influence of agronomic application of Olive mill wastewater $(30,60$, 100 and $150 \mathrm{~m}^{3} \mathrm{ha}^{-1}$ ) significantly increase in organic C, $\mathrm{C} / \mathrm{N}$ ratio, extractable phosphorus and exchangeable potassium. Biswas (2009) reported that the use of distillery effluent, a waste by-product of distillery industries as irrigation water or as a soil amendment showed significant effect on soil organic carbon of Vertisol. Jeremy et al. (2009) observed that variability of soil $\mathrm{pH}$, organic matter $(\mathrm{OM})$, cation exchange capacity (CEC), total nitrogen (TN), total phosphorus (TP), available phosphorus and available potassium on Cambosols and Anthrosols in Zhangjiagang County, China due to increase the annual application of $\mathrm{N}$ fertilizer and $\mathrm{P}$ fertilizer rates. Fertilizer input rates are causing nutrient imbalances, contributing to acidification in Anthrosols, and decreasing $\mathrm{C} / \mathrm{N}$ ratios. Mohammadi et al. (2010) concluded that the use of paper mill lime sludge as a soil amendment in an acidic soil was significantly increased $\mathrm{pH}$, which was proportional to the application rate of paper mill sludge. The application of $2 \%$ sludge (based on soil dry mass) remarkably increased shoot dry matter and P, K, Fe, Mn, K and P uptake. Osadebamwen (2010) observed that the soil was treated with seven rates of abattoir effluent (viz. 0, 25, 50, 100,125 and $150 \mathrm{ml} / \mathrm{kg}$ soil), the effluent application increased $\mathrm{pH}$, available $\mathrm{P}$ and micronutrients $(\mathrm{Zn}, \mathrm{Mn}$ and $\mathrm{Fe}$ ) significantly in the soil whilst exchangeable cations were reduced significantly when compared to the control.

M oisture content, Soil texture, W HC and BD: During the present study, the soil moisture content was decreased $(67.38$ to $53.61 \%)$ on irrigation with different concentrations of the SME. The increasing dose of effluent considerably reduced the bulk density of the surface soil (Table 4). The BD was minimum $\left(1.39 \mathrm{~g} \mathrm{~cm}^{-3}\right)$ in $100 \%$ of SME followed by $75 \%, 50 \%, 25 \%, 10 \%$ and $5 \%$. The BD was maximum $\left(1.45 \mathrm{~g} \mathrm{~cm}^{-3}\right)$ in control, which was insignificantly different $(\mathrm{P}>0.05)$ with the concentrations of SME. The available water content varied from the control soil $48.23 \%$ to $41.57 \%$ with $100 \%$ concentration of SME (Table 2). The ANOVA analysis on data showed that the soil moisture content, WHC and 
Table 3. Regression linear equation relating added R.B.N.S. sugar mill effluents to soil characteristics.

\begin{tabular}{|c|c|c|}
\hline Effluent/soil characteristics & Regression equation & $\mathrm{R}^{2}$ \\
\hline Sugar mill effluent versus soil moisture content & $y=65.957-0.1402 x$ & 0.889 \\
\hline Sugar mill effluent versus soil WHC & $y=47.254-0.0635 x$ & 0.884 \\
\hline Sugar mill effluent versus soil BD & $y=1.4481-0.0007 x$ & 0.952 \\
\hline Sugar mill effluent versus soil $\mathrm{pH}$ & $y=7.6057+0.0071 x$ & 0.943 \\
\hline Sugar mill effluent versus soil EC & $y=2.4887+0.0112 x$ & 0.799 \\
\hline Sugar mill effluent versus soil ECEC & $y=10.773+0.1647 x$ & 0.923 \\
\hline Sugar mill effluent versus soil $\mathrm{Cl}^{-}$ & $y=117.35+1.7689 x$ & 0.831 \\
\hline Sugar mill effluent versus soil OC & $y=3.3953+0.1221 x$ & 0.895 \\
\hline Sugar mill effluent versus soil $\mathrm{HCO}_{3}^{-}$ & $y=390.91+0.7327 x$ & 0.950 \\
\hline Sugar mill effluent versus soil $\mathrm{CO}_{3}^{-2}$ & $y=230.39+0.695 x$ & 0.986 \\
\hline Sugar mill effluent versus soil $\mathrm{Na}^{+}$ & $y=23.345+0.3102 x$ & 0.945 \\
\hline Sugar mill effluent versus soil $\mathrm{K}^{+}$ & $y=181.6+0.6576 x$ & 0.734 \\
\hline Sugar mill effluent versus soil $\mathrm{Ca}^{2+}$ & $y=24.261+1.9663 x$ & 0.987 \\
\hline Sugar mill effluent versus soil $\mathrm{Mg}^{2+}$ & $y=3.2074+0.3166 x$ & 0.980 \\
\hline Sugar mill effluent versus soil TKN & $y=48.682+4.0102 x$ & 0.985 \\
\hline Sugar mill effluent versus soil $\mathrm{NO}_{3}{ }^{2-}$ & $y=39.086+0.3319 x$ & 0.989 \\
\hline Sugar mill effluent versus soil $\mathrm{PO}_{4}^{3-}$ & $y=79.813+1.1461 x$ & 0.865 \\
\hline Sugar mill effluent versus soil $\mathrm{SO}_{4}{ }^{2-}$ & $y=76.113+0.5814 x$ & 0.954 \\
\hline Sugar mill effluent versus soil $\mathrm{Fe}^{2+}$ & $y=3.554+0.0619 x$ & 0.923 \\
\hline Sugar mill effluent versus soil $\mathrm{Zn}$ & $y=1.2762+0.0238 x$ & 0.800 \\
\hline Sugar mill effluent versus soil $\mathrm{Cd}$ & $y=0.094+0.0017 x$ & 0.811 \\
\hline Sugar mill effluent versus soil $\mathrm{Cu}$ & $y=3.2144+0.0768 x$ & 0.857 \\
\hline Sugar mill effluent versus soil $\mathrm{Pb}$ & $y=0.0507+0.0025 x$ & 0.883 \\
\hline Sugar mill effluent versus soil $\mathrm{Cr}$ & $y=0.155+0.0128 x$ & 0.984 \\
\hline
\end{tabular}

$\mathrm{BD}$ was recorded to be insignificantly $(\mathrm{P}>0.05)$ affected with different concentration of SME in comparison to control irrigated soil (Table 2). The regression equation and $\mathrm{R}^{2}$ value, $88 \%, 88 \%$ and $95 \%$ of the variation in soil moisture, WHC and BD content was represented for by SME (Table 3). During present study, the soil characteristics have been found to change on irrigation with SME. It was observed that the soil particle size depicted that the experimental soil was of loamy sand type (Table 3). This reduction in BD was due to higher organic matter content in the treatments where SME was added in higher doses. Haynes and Naidu (1998) and Celik (2005) also reported a reduction in BD with addition of organic matter. The BD showed insignificant $(\mathrm{P}>0.05)$ and negative linear relationship with the soil organic carbon. Weil and Kroontje (1979) also observed a negative linear relationship between soil organic matter content and BD on a soil amended with increasing rates of poultry manure application. Webber (1978) and Weil and Kroontje (1979) have reported increased retention of soil water with an increase in waste application rate. An increased WHC at low tensions such as FC was primarily due to increased number of small pores caused by the improvement in aggregation in the soil (Haynes and Naidu, 1998).Treatment differences had not shown any significant effect on the WHC. The moisture content of soil is useful and an important factor which affects the $\mathrm{pH}$, availability of nutrient to plant and aeration. The moisture content and overall water content in soil at any moment are governed by the amount of water coming and going out from soil. Presence of large soil particles reduces the soil moisture content (Khaleel et al., 1981; Miller and Turk, 2002). Water holding capacity is related to the number and size distribution of soil pores and consequently increases with soil organic matter level. It is related to soil moisture content, textural class, structure, salt content and organic matter. Barzegar et al. (2002) found that water content of soils did not change with the rate and type of organic matter. Organic matter supplied through the sludge and other kind of wastes also lower the bulk density as stated by (Ramulu, 2001). The decrease in moisture content from control irrigated soil $(45.33 \%)$ to (38.67\%) in $100 \%$ concentration of paper mill effluent irrigated soil was also reported earlier by (Vinod et al., 2010).

$\mathrm{pH}$ and EC: During the present study the soil $\mathrm{pH}$ was recorded initial level (7.53) alkaline and it was turned to more alkaline (8.25) with $100 \%$ concentration of SME. The effluent concentration 50\%, 75\% and $100 \%$ of SME showed significant $(\mathrm{P}<0.05)$ effect on soil $\mathrm{pH}$ in comparison to control soil (Table 2). The regression equation and $\mathrm{R}^{2}$ value, $94 \%$ of the variation in soil $\mathrm{pH}$ was recorded for by SME (Table 3). Soil $\mathrm{pH}$ change to alkaline with application of SME significantly. High buffering capacity of the clay soil and nominal presence of any weak salts namely carbonates or bicarbonates, which on dissolution release free cations, might be the possible causes for the stability of the soil reaction. This is the $\mathrm{pH}$ range of maximum nutrient availability in the soils (Brady and Weil 2005). The $\mathrm{pH}$ levels that resulted 


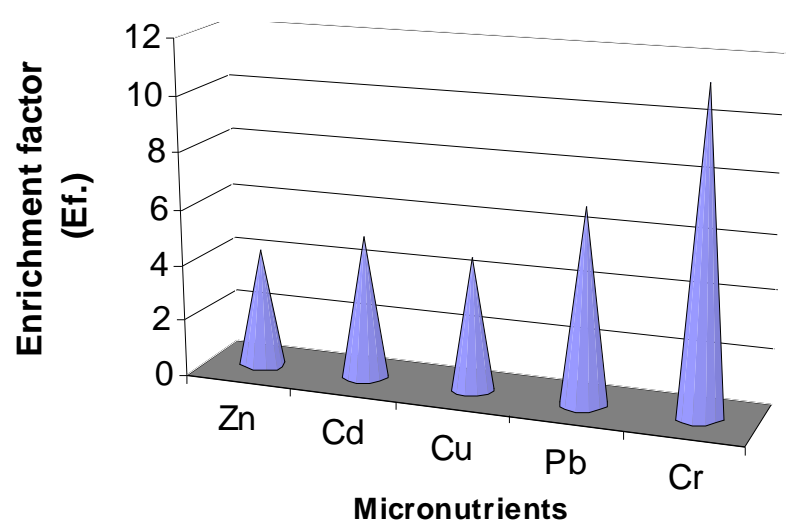

\begin{tabular}{|c|c|c|c|c|c|}
\cline { 2 - 6 } \multicolumn{1}{c|}{} & $\mathrm{Zn}$ & $\mathrm{Cd}$ & $\mathrm{Cu}$ & $\mathrm{Pb}$ & $\mathrm{Cr}$ \\
\hline$\square$ Micronutrients & 4.18 & 5.04 & 4.74 & 6.86 & 11.24 \\
\hline
\end{tabular}

Fig.1. Enrichment factor of various micronutrients in soil after irrigation with R.B.N.S. sugar mill effluent.

from the different levels of pollution appeared favourable to both biological and chemical reactions in the soils (Brady and Weil 2005).

The increase in the rate of application of effluent significantly $(\mathrm{P}<0.001)$ increased the EC of the soil (Table 2). It was recorded to be significantly different with $5 \%$ to $100 \%$ concentration of SME in comparison to control soil. The effluent treated plots registered significantly higher EC $\left(3.45 \mathrm{dS} \mathrm{m}^{-1}\right)$ than control $\left(2.10 \mathrm{dS} \mathrm{m}^{-1}\right)$ this was due to very high salt load $\left(8.65 \mathrm{dS} \mathrm{m}^{-1}\right)$ EC of the SME. The regression equation and $R^{2}$ value, $79 \%$ of the variation in soil EC was recorded for by SME (Table 3). Similar findings were also reported by Chonker et al. (2000) and Raverkar et al. (2000). The increase in EC from control irrigated soil $\left(1.03 \mathrm{dS} \mathrm{m}^{-1}\right)$ to $\left(2.26 \mathrm{dS} \mathrm{m}^{-1}\right)$ in $100 \%$ concentration of paper mill effluent irrigated soil was also reported earlier by (Vinod et al., 2010).

Effective cation exchange capacity: The ECEC was increased in the SME irrigated soil were increased significantly from initial level $12.00-29.91 \mathrm{cmol} \mathrm{Kg}^{-1}$ in $100 \%$ of SME. The ECEC of the SME irrigated soil was found to be significantly $(\mathrm{P}<0.001)$ different with $50 \%$ to $100 \%$ concentrations of SME (Table 2). The regression equation and $\mathrm{R}^{2}$ value, $92 \%$ of the variation in soil ECEC was recorded for by SME (Table 3). The decrease in ECEC from (7.71-3.19 $\left.\mathrm{cmol} \mathrm{Kg}^{-1}\right)$ was recorded in abattoir effluent irrigated soil by Osadebamwen (2010).

Chlorides: The chlorides in the SME irrigated soil were increased with the effluent concentration increased. The SME concentrations 5, 10, 25, 50, 75 and $100 \%$ showed significant $(\mathrm{P}<0.001)$ effect on chlorides of the soil in comparison to control soil (Table 2). The regression equation and $R^{2}$ value, $83 \%$ of the variation in soil chlorides was recorded for by SME (Table 3). Chlorides in the SME irrigated soil were increased significantly from initial level $89.43-263.56 \mathrm{mg} \mathrm{Kg}^{-1}$ in $100 \%$ of SME. The increase in chlorides from control irrigated soil $(32.32 \mathrm{mg}$
$\left.\mathrm{Kg}^{-1}\right)$ to $\left(50.87 \mathrm{mg} \mathrm{Kg}^{-1}\right)$ in $100 \%$ concentration of paper mill effluent irrigated soil was also reported earlier by (Vinod et al., 2010).

Organic car bon: The organic carbon content of the soil increased considerably with the application of SME. It increased from an initial level of $0.45-14.98 \mathrm{mg} \mathrm{Kg}^{-1}$ in $100 \%$ of SME. The soil organic carbon was found to be significantly $(\mathrm{P}<0.001)$ different with $5 \%$ to $100 \%$ concentrations of SME (Table 2). The regression equation and $\mathrm{R}^{2}$ value, $89 \%$ of the variation in soil organic carbon was recorded for by SME (Table 3). Addition of organic matter through effluent and better crop growth with concomitant increase in root biomass could be the probable reasons for the improvement in organic carbon content particularly in high SME treated plots. The results of Zalawadia and Raman (1994) and Pathak et al. (1999) support these findings.

Bicarbonates and carbonates: The bicarbonates and carbonates content of the soil increased significantly with the appliance of SME. It increased from an initial level of $383.64-469.36 \mathrm{mg} \mathrm{Kg}^{-1}$ and $229.65-297.12 \mathrm{mg} \mathrm{Kg}^{-1}$ in $100 \%$ of SME respectively. The effluent concentration $10 \%$ to $100 \%$ of SME showed significant $(\mathrm{P}<0.001)$ affect on bicarbonates and carbonates in the SME irrigated soil (Table 2). The content of bicarbonates in the soil was also recorded significantly different with $5 \%$ concentration of SME. The regression equation and $\mathrm{R}^{2}$ value, $95 \%$ and $98 \%$ of the variation in soil bicarbonates and carbonates were recorded for by SME (Table 3). Clays, organic matter oxides of $\mathrm{Al}$ and $\mathrm{Fe}, \mathrm{Ca}$ and $\mathrm{Mg}$ carbonates are the components responsible for $\mathrm{pH}$ buffering in most soils. The soil $\mathrm{pH}$ can also influence plant growth by the $\mathrm{pH}$ effect on activity of beneficial microorganisms. Most nitrogen fixing legume bacteria is not very active in strongly acidic soils. Bacteria that decompose organic matter and thus release nitrogen and 
other nutrients for plant use are also hindered by strong acidity.

Exchangeable sodium, potassium, calcium and magnesium: On irrigation with of SME the exchangeable sodium, potassium, calcium and magnesium were found to be changed with different concentrations of the effluent. The effluent concentrations 10\%, 25\%, 50\%, $75 \%$ and $100 \%$ of PME showed significant $(\mathrm{P}<0.001)$ change in the content on $\mathrm{Na}, \mathrm{K}, \mathrm{Ca}$ and $\mathrm{Mg}$ in comparison to control soil. It was quite interesting to note that the content of $\mathrm{K}$ and $\mathrm{Ca}$ were also recorded to be significantly $(\mathrm{P}<0.001)$ different with 5\% concentration of SME (Table 2 ). The regression equation and $\mathrm{R}^{2}$ value, $94 \%, 73 \%, 98 \%$ and $68 \%$ of the variation in soil $\mathrm{Na}, \mathrm{K}, \mathrm{Ca}$ and $\mathrm{Mg}$ were found for by SME (Table 3). The content of exchangeable sodium, potassium, calcium and magnesium were increased significantly from an initial (control) level of 18.81-53.70 $\mathrm{mg} \mathrm{Kg}^{-1}, 155.34-238.29 \mathrm{mg} \mathrm{Kg}^{-1}, 15.36-209.24$ mg Kg${ }^{-1}$ and $1.70-32.61 \mathrm{mg} \mathrm{Kg}^{-1}$ in $100 \%$ of SME respectively. The increase in $\mathrm{Na}, \mathrm{K}$ and $\mathrm{Ca}$ from control irrigated soil (42.86 mg Kg ${ }^{-1}, 129.29 \mathrm{mg} \mathrm{Kg}^{-1}, 51.05 \mathrm{mg} \mathrm{Kg}^{-}$ 1) to $\left(59.49 \mathrm{mg} \mathrm{Kg}^{-1}, 146.83 \mathrm{mg} \mathrm{Kg}^{-1}\right.$ and $\left.60.59 \mathrm{mg} \mathrm{Kg}^{-1}\right)$ respectively in $100 \%$ concentration of paper mill effluent irrigated soil was also reported earlier (Vinod et al., 2010). Total nitrogen, nitrate, phosphate and sulphates: The content of total nitrogen, nitrate, phosphate and sulphates were increased significantly from an initial (control) level of 32.21-420.78 mg Kg-1 $39.32-71.12 \mathrm{mg}$ $\mathrm{Kg}^{-1}$, 53.00-178.10 mg Kg${ }^{-1}$ and 74.37-127.98 mg Kg-1 in $100 \%$ of SME respectively. The effluent concentrations $25 \%, 50 \%, 75 \%$ and $100 \%$ of SME showed significant $(\mathrm{P}<0.001)$ change in total nitrogen, nitrate, phosphate and sulphates of the soil. It was quite interesting to note that the total nitrogen and phosphate of soil were also recorded to be significantly different with $5 \%$ and $10 \%$ concentration of SME. The regression equation and $\mathrm{R}^{2}$ value, $98 \%, 98 \%, 86 \%$ and $95 \%$ of the variation in soil TKN, nitrate, phosphate and sulphates was found for by SME (Table 3). The increase in nitrate, phosphate and sulphate from control irrigated soil $\left(31.01 \mathrm{mg} \mathrm{Kg}^{-1}, 11.96\right.$ $\mathrm{mg} \mathrm{Kg}{ }^{-1}$ and $\left.41.41 \mathrm{mg} \mathrm{Kg}^{-1}\right)$ to $\left(42.31 \mathrm{mg} \mathrm{Kg}^{-1}, 19.53 \mathrm{mg}\right.$ $\mathrm{Kg}^{-1}$ and $52.02 \mathrm{mg} \mathrm{Kg}^{-1}$ ) respectively in $100 \%$ concentration of paper mill effluent irrigated soil was also reported earlier (Vinod et al., 2010).

$\mathrm{M}$ icronutrients: The concentration of micronutrients viz. $\mathrm{Fe}, \mathrm{Zn}, \mathrm{Cd}, \mathrm{Cu}, \mathrm{Pb}$, and $\mathrm{Cr}$ were recorded to be significantly $(\mathrm{P}<0.001)$ affected with $25 \%$ to $100 \%$ concentration of SME. The content of $\mathrm{Fe}, \mathrm{Zn}, \mathrm{Cd}, \mathrm{Cu}$, and $\mathrm{Cr}$ were found to be significantly $(\mathrm{P}<0.001)$ different with $10 \%$ concentration of SME irrigated soil. It was quite interesting to note that the content of $\mathrm{Fe}, \mathrm{Cd}$, and $\mathrm{Cu}$, were also found to be significantly $(\mathrm{P}<0.001)$ different with 5\% concentration of SME irrigated soil (Table 2). The regression equation and $\mathrm{R}^{2}$ value, $92 \%, 80 \%, 81 \%$,
$85 \%, 88 \%$ and $98 \%$ of the variation in soil $\mathrm{Fe}, \mathrm{Zn}, \mathrm{Cd}, \mathrm{Cu}$, $\mathrm{Pb}$, and $\mathrm{Cr}$ were recorded for SME (Table 3). Among the micronutrients the maximum enrichment factor (Ef) was shown by $\mathrm{Cr}$ (11.24) while the minimum by $\mathrm{Zn}$ (4.18) and it was in order of $\mathrm{Cr}>\mathrm{Pb}>\mathrm{Cd}>\mathrm{Cu}>\mathrm{Zn}$ after irrigation with SME (Fig.1). Under acidic conditions, elements such as iron, aluminium, manganese and the heavy metals (zinc, copper, and chromium) become highly soluble and may create problems for vegetation (Charman and Murphy, 1991). The content of $\mathrm{Fe}, \mathrm{Zn}, \mathrm{Cd}, \mathrm{Cu}, \mathrm{Pb}$ and $\mathrm{Cr}$ were increased significantly with the application of SME. It increased from an initial (control) level of Fe (2.65-8.86 $\left.\mathrm{mg} \mathrm{Kg}^{-1}\right), \mathrm{Zn}\left(0.790-3.300 \mathrm{mg} \mathrm{Kg}^{-1}\right), \mathrm{Cd}(0.046-0.232 \mathrm{mg}$ $\left.\mathrm{Kg}^{-1}\right), \mathrm{Cu}\left(2.028-9.631 \mathrm{mg} \mathrm{Kg}^{-1}\right), \mathrm{Pb}\left(0.035-0.261 \mathrm{mg} \mathrm{Kg}^{-1}\right)$ and $\mathrm{Cr}\left(0.125-1.406 \mathrm{mg} \mathrm{Kg}^{-1}\right)$ to $100 \%$ of SME irrigated soil. This is in agreement with what was reported by other workers that organic wastes contain high amounts of macro and micronutrients (Roy et al., 2007; Chandra et al., 2009).

\section{Conclusion}

The present study concluded that the effluent of the R.B.N.S. sugar mill, Laksar, Haridwar (Uttarakhand) decreased the moisture content WHC, and bulk density and increased the $\mathrm{pH}, \mathrm{EC}, \mathrm{Cl}$, OC, $\mathrm{HCO}_{3}^{-}, \mathrm{CO}_{3}^{-2}, \mathrm{Na}^{+}, \mathrm{K}^{+}$, $\mathrm{Ca}^{2+}, \mathrm{Mg}^{2+}, \mathrm{Fe}^{2+}, \mathrm{TKN}, \mathrm{NO}_{3}^{2-}, \mathrm{PO}_{4}^{3-}, \mathrm{SO}_{4}^{2-}$ and $\mathrm{Zn}, \mathrm{Cd}, \mathrm{Cu}$, $\mathrm{Pb}$ and $\mathrm{Cr}$ of the soil. The micronutrients such as $\mathrm{Fe}, \mathrm{Zn}$, $\mathrm{Cd}, \mathrm{Cu}, \mathrm{Pb}$ and $\mathrm{Cr}$ were also recorded higher in the soil irrigated with SME which may lead to toxicity of soil at higher concentration in comparison to control. The results indicated that nutrients and trace elements of sugar mill effluent irrigation contributed significant changes to the soil quality and affected the natural composition of the soil. Such alterations improved the fertility and enhanced the nutrients status of soil after effluent irrigation. Thus, effluent irrigation improved the soil nutrient status. All effluent concentrations were better than the control in nutrient accumulation. The enrichment factor (Ef) indicated the accumulation of various micronutrients in the soil after SME irrigation. The order of enrichment factor (Ef) of various heavy metals $\mathrm{Cr}>\mathrm{Pb}>\mathrm{Cd}>\mathrm{Cu}>\mathrm{Zn}$ were recorded in the soil after irrigation with SME. Thus application of SME to the agricultural field, as an amendment, might be a viable option for the safe disposal of this industrial waste with concomitant improvement in physical properties of the soil and enhancement in yield. However, the level of application should be within the prescribed limit to avoid development of soil salinity/ sodicity in the long run.

\section{ACKNOWLEDGEMENTS}

The University Grants Commission, New Delhi, India is acknowledged for providing the financial support in the form of UGC research fellowship (F.7-70/2007-09 BSR) to Dr. Vinod Kumar. 


\section{REFERENCES}

Aber, J., McDowell, W., Nadelhoffer, K., Magill, A., Berntson, G., Kamakea, M., McNulty, S., Currie, W., Rustad, L. and Fernandez, I. (1998). Nitrogen saturation in northern forest ecosystems: hypotheses revisited. Bio Science, 48: 921-934.

Afshin Qishlaqi, Farid Moore and Giti Forghani (2008). Impact of untreated wastewater irrigation on soils and crops in Shiraz suburban area, SW Iran. Environ M onit Assess, 141: 257-273.

Ågren, G.I. and Bosatta, E. (1998). Nitrogen saturation of terrestrial ecosystems. Environ. Pollut, 54: 185-197.

Al-Harbi, A.R. Wahb-Allah, M.A. and Abu-Muriefah, S.S. (2008). Salinity and nitrogen level affects germination emergence, and seedling growth of tomato. International J ournal of Vegetable Science, 14 (4): 380-392.

APHA (2005). In: Standard M ethods for the Examination of Water and Wastewater. American Public Health Association (APHA), American Water Works Association (AWWA) \& Water Environment Federation (WEF), 21st edition, Washington, DC. pp 1368.

Arindam, K. and Prasad, A.B. (1999). Alteration in physicochemical characteristics of soil under stress of carbonaceous sugar mill. Ad. Plant Sci. 12: 103-109.

Ayyasamy, P. M., Yasodha, R., Rajakumar S., Lakshmanaperumalsamy, P., Rahman P. K. S. M. and Sanghoon Lee (2008). Impact of Sugar Factory Effluent on the growth and Biochemical characteristics of Terrestrial and Aquatic Plants. Bull Environ Contam Toxicol, 81:449454.

Barzegar, A.R., Yousefi, A. and Daryashenas, A. (2002). The effect of addition of different amounts and types of organic materials on soil physical properties and yield of wheat. Soil Tillage Res., 247 (2): 295 - 301

Baruah, A.K., Sharma, R.N. and Borah, G.C. (1993). Impact of sugar mill and distillery effluent on water quality of river Galabil, Assam. Indian J Environ HIth., 35:288-293.

Beligh Mechri, Fethi Ben Mariem, Mohamed Baham, Salem Ben Elhadj and Mohamed Bibin Paulose, Siba P. Datta, Raj K. Rattan, Pramod K. Chhonkar (2007). Effect of amendments on the extractability, retention and plant uptake of metals on a sewage-irrigated soil. E nvironmental Pollution 146: 19-24

Biswas, A.K., Mohanty, M., Hati, K.M. and Misra A.K. (2009). Distillery effluents effect on soil organic carbon and aggregate stability of a Vertisol in India. Soil \& Tillage Research, 104 (2): 241-246.

Bharagava, R.N., Chandra, R. and Rai, V. (2008). Phytoextraction of trace elements and physiological changes in Indian mustard plants (Brassica nigra L.) grown in post methanated distillery effluent (PMDE) irrigated soil. Bioresource Technology, 99 (17): 8316-8324.

BIS (1991). In: Indian Standards for drinking waterSpecification (BIS 10500:1991) retrieved on 20 ${ }^{\text {th }}$ April, 2007 from (http:// www.bis.org.in).

Bouyoucos, G.J. (1962). Hydrometer method improved for making particle size analysis of soils. Agron. J., 54: 464.

Brady, N. C. and Weil, R. R. (2005). The nature and properties of soils, 13th ed. Delhi: Pearson Education.

Buurman, P.B., Van Langer, and Velthrost, E.J. (1996). In:
Manual of Soil and water analysis. Backhuys Publisher, Leiden, The Netherland.

Carter, M.R. (1993). In: Soil sampling and method of analysis, Lewis Publishers, Boca Raton, FL.

Celik, I. (2005). Land use effects on organic matter and physical properties of soil in a southern Mediterranean highland of Turkey. Soil \& Tillage Research, 83: 270- 277.

Chandra, R., Bharagava, R.N., Yadav, S. and Mohan D. (2009). Accumulation and distribution of toxic metals in wheat (Triticum aestivum L.) and Indian mustard (Brassica campestris L.) irrigated with distillery and tannery effluents. J ournal of H azardous M aterials, 162 (2-3): 1514-1521.

Charman, P.E.V. and Murphy, B.W. (1991). In: Soils: Their Properties and Management. In a Soil Conservation Handbook for New South Wales. Sydney University Press. Sydney.

Chin-Ching Lin, Arun, A.B., Rekha, P.D. and Chiu-Chung Young (2008). Application of wastewater from paper and food seasoning industries with green manure to increase soil organic carbon: A laboratory study. Bioresource Technology, 99 (14): 6190-6197.

Chonker, P.K., Datta, S.P., Joshi, H.C. and Pathak, H. (2000). Impact of industrial effluents on soil health and agricultureIndian experience. Part I: distillery and paper mill effluents. J. Scientific Ind. Res., 59: 350-361.

Chopra, A.K., Chakresh Pathak and Parasad, G. (2009). Scenario of heavy metal contamination in agricultural soil and its management. J. Appl. \& Nat. Sci., 1(1): 99-108.

García-Orenes, F., Guerrero, C., Mataix-Solera, J., NavarroPedreño, J., Gómez, I. and Mataix-Beneyto J. (2005). Factors controlling the aggregate stability and bulk density in two different degraded soils amended with biosolids. Soil and Tillage Research, 82 (1): 65-76.

Gomez, E., Ferreras, L., Toresani, S., Ausilio, A. and Bisaro V. (2001). Changes in some soil properties in a Vertic Argiudoll under short-term conservation tillage. Soil and Tillage Research, 61 (3-4): 179-186.

Hassanli Ali Morad, Mohammad Ali Ebrahimizadeh, Simon Beecham (2009). The effects of irrigation methods with effluents and irrigation scheduling on water use efficiency and corn yields in an arid region. Agricultural Water M anagement, 96(1): 93-99.

Hati, K.M., Biswas, A.K., Bandyopadhyay, K.K. and Misra, A.K. (2007). Soil properties and crop yields on a vertisol in India with application of distillery effluent. Soil and Tillage Research, 92 (1-2): 60-68.

Haynes, R. J. and Naidu, R. (1998). Influence of lime, fertilizer and manure applications on soil organic matter content and soil physical conditions: a review. Nutrient Cycling in Agroecosystems, 51:123-137.

Hussain, Intizar, Liqa Raschid, Munir, A., Hanjra, Fuard Marikar, Wim van der Hoek., (2001). Framework for analyzing socioeconomic, health and environmental impacts of wastewater use in agriculture, IWMI working paper 26. International Water Management Institute, Colombo: Sri Lanka.

Jeremy, L. Darilek, Biao Huang, Zhigang Wang, Yanbing Qi, Yongcun Zhao, Weixia Sun, Zhiquan Gu and Xuezheng Shi (2009). Changes in soil fertility parameters and the environmental effects in a rapidly developing region of China. 
Agriculture, Ecosystems and Environment, 129: 286-292

Kannan, A. and Upreti, Raj K. (2008). Influence of distillery effluent on germination and growth of mung bean (Vigna radiata, L.R. Wilczek) seeds. Journal of Hazardous Materials, 53(1-2): 609-615.

Kaushik, A., Bala R. Kadyan and Kaushik, C.P. (1996). Sugar mill effluent effects on growth and photosynthetic pigments and nutrients uptake in wheat seedlings in aqueous Vs. soil medium. Water, Air and Soil Pollution, 87: 39-46.

Kaushik, A. Nisha, R., Jagjeeta, K. and Kaushik, C.P. (2005). Impact of long and short term irrigation of a sodic soil with distillery effluent in combination with bioamendments. Bioresource Technology, 96 (17): 1860-1866.

Kim, K. H., and Kim, S. H. (1999). Heavy metal pollution of agricultural soils in central regions of Korea. Water, Air, and Soil Pollution, 111: 109-122.

Khaleel, R., Reddy, K.R. and Overcash, M.R. (1981). Changes in soil physical properties due to organic waste applications: a review. J ournal of Environmental Quality, 10:133-141.

Miller, C.E. and Turk, L.M. (2002). Fundamentals of soil science. Biotech. Books, 1123/74, Trinagar, Delhi: 157.

Mohan, S.C., Samra, J.S, Srivastava, A.K. and Sharda, V.N. (2007). Training manual on soil conservation and watershed management, Vol-I, soil, Agronomy and socio-economic aspects. Central soil \& water conservation research \& training institute, Dehradun, (U.K), India: pp 42.

Mohammad Ajmal and Ahsan Ullah Khan (1985). Effects of a textile factory effluent on soil and crop plants. Environmental Pollution (Series A), 37: 131-148.

Mohammadi, A. Torkashvand, Haghighat, N. and Shadparvar, V. (2010). Effect of paper mill lime sludge as an acid soil amendment. Scientific Research and Essays, 5(11): 13021306.

Nastri, A., Ramieri, N.A., Abdayem, R., Piccaglia, R., Marzadori, C. and Ciavatta C. (2006). Olive pulp and its effluents suitability for soil amendment. Journal of Hazardous M aterials, 138 (2): 211-217.

Osadebamwen Ikpotokin Osemwota (2010). Effect of abattoir effluent on the physical and chemical properties of soils. Environ M onit Assess, 167 (1-4): 399-404. (DOI 10.1007/ s10661-009-1058-7).

Osemwota, I. O., Ogboghodo, A. I., Okpefa, G. O. and Njukwe, K. E. (2000). Characterization of soils of Edo State of Nigeria for the computation of phosphorus fertilizer factor. Indian J ournal of Agricultural Research, 34(2): 71-77.

Osemwota, I. O., Ogboghodo, I. A. and Aghimien, E. A. (2005). Phosphorus retention in soils of Nigeria: A review. Agricultural Review, 26(2): 148-152.

Patterson, S. J., Chanasyk D. S., Mapfumo, E. and Naeth, M. A. (2008). Effects of diluted Kraft pulp mill effluent on hybrid poplar and soil chemical properties. Irrig Sci, 26: 547-560. (DOI 10.1007/s00271-008-0115-2).

Pathak, H., Joshi, H.C., Chaudhary, A., Chaudhary, R., Kalra, N. and Dwiwedi, M.K. (1999). Soil amendment with distillery effluent for wheat and rice cultivation. Water Air Soil Pollut., 113: 133-140.

Ramana, S., Biswas, A.K., Kundu, S., Saha, J.K. and Yadava, R.B.R. (2002). Effect of distillery effluent on seed germination in some vegetable crops. Bioresource Technology, 82 (3): 273-275.

Ramulu Sree, U.S. DR. (2001). Reuse of municipal sewage and sludge in agriculture. Scientific publishers (India), Jodhpur: 86.

Raverkar, K.P., Ramana, S., Singh, A.B., Biswas, A.K. and Kundu, S. (2000). Impact of post methanated spent wash (PMS) on the nursery raising, biological Parameters of Glyricidia sepum and biological activity of soil. Ann. Plant Research, 2(2): 161- 168 .

Roy, P. Ratna, Jagdish Prasad and Joshi, A.P. (2007). Effect of sugar factory effluent on some physico-chemical properties of soils- A case study. J our nal of Environ. Science \& Engg., 49(4): 277-282.

Sanjay, K. Solomon (2005). Environmental Pollution and Sugar Industry in India its Management in: An Appraisal. Sugar Tech., 7 (1): 77-81.

Sharif A. Salah and Suzelle F. Barrington (2006). Effect of soil fertility and transpiration rate on young wheat plants (Triticum aestivum) $\mathrm{Cd} / \mathrm{Zn}$ uptake and yield. Agricultural Water M anagement, 82: 177-192.

Stoecio M.F. Maia, Stephen M. Ogle Carlos C. Cerri and Carlos E.P. Cerri (2010). Changes in soil organic carbon storage under different agricultural management systems in the Southwest Amazon Region of Brazil. Soil \& Tillage Research, 106: 177-184.

Tan, K. H. (1996). Determination of micro elements. In: Soil sampling, preparation and analysis, (pp. 189-198). New York: Marcel Dekker INC.

Thompson, G., Swain, J., Kay, M. and Forster, C.F. (2001). The treatment of pulp and paper-mill effluent: A review. Bioresource Technology, 77 (3): 275-286.

Tse-Ming Lee, Hung-Yu Lai and Zueng-Sang Chen (2004). Effect of chemical amendments on the concentration of cadmium and lead in long-term contaminated soils. Chemosphere, 57: 1459-1471.

Vinod Kumar, Chopra, A.K., Chakresh Pathak and Sachin Pathak (2010). Agro-potentiality of paper mill effluent on the characteristics of Trigonella foenum-graecum L. (Fenugreek). N ew York Science J ournal, 3(5): 68-77.

Webber, L.R. (1978). Incorporation of non-segregated noncomposted solid waste and soil physical properties. J . Environ. Qual., 7: 397-400.

Weil, R.R. and W. Kroontje 1979). Physical condition of a Davidson clay loam after five years of heavy poultry manuare applications. J. Environ. Qual., 8: 387-392.

Zalawadia, N.M.and Raman, S. (1994). Effect of distillery wastewater with graded fertilizer levels on sorghum yields and soil property. J. Indian Soc. Soil Sci., 42: 575-579. 